\title{
Evaluation of chemical and microbiological quality of white pickled soft cheese consumed in Minia governorate .
}

\author{
Raghda.M.S.Moawad ${ }^{1}$ and Osama .S.F.Khalil ${ }^{2}$ \\ ${ }^{1}$ Dairy Science Department, Faculty of Agriculture, Minia University, Egypt . \\ ${ }^{2}$ Dairy Science and Technology Department, Faculty of Agriculture and Natural Resources, \\ Aswan University, Aswan, 81528, Egypt.
}

Received on: $28-5-2021$

Accepted on: 16-8-2021

\begin{abstract}
This study aimed to evaluate the chemical and microbiological quality of white pickled cheese cons umed in some districts of Minia governorate.

In this study 24 samples of unpacked white pickled soft cheese were collected from different local markets in Minia Governorate. Samples were divided into six brands, each brand includes four samples, and analyzed chemically and microbiologically.

Chemical analys is were 4.2-4.6 for $\mathrm{pH}, 3.0$-3.7 \% titratable acidity , 43.3-54 \% total solids , 18.1-25.9\% fat , 19.43-19.8\% protein , $7.3-11.3 \%$ salt , 7.0-8.6\% ash , 0.25-0.27 \% soluble nitrogen , 312- $1651 \mathrm{mg} / 100 \mathrm{~g}$ for calcium and 263-368 $\mathrm{mg} / 100 \mathrm{~g}$ phos phorus .

Microbiological analysis data showed that the average of total aerobic bacteria was $4.8 \times 10^{5} \pm 1 \times 10^{5} \mathrm{cfu} / \mathrm{ml}$. Lactococci, Lactobacilli , molds \& yeasts and E.coli were $5.7 \pm 1 \times 10^{3}, 1.6 \pm 0.2 \times 10^{5}, 5.1 \pm 0.35 \times 10^{5}$ and $3.7 \pm 0.1 \times 10^{1} \mathrm{cfu} / \mathrm{ml}$, respectively . Results revealed that 58.3 and $41.5 \%$ of samples were positive for Coliform and Enterobacteriacae . The identified microbial groups also cleared that salmonella was the predominant of about $9 \%$ of the total tested groups . In conclusion, it should be taken in considered the urgent need to manufacture white soft pickled cheese with a criteria or standard method.
\end{abstract}

KEYWORDS: Soft cheese, pathogenic bacteria, titratable acidity and unpacked.

\section{INTRODUCTION}

Cheese is considered as an essential daily food for many people around the world. It has a nutritional value that provides an essential source of digestible protein and minerals, including calcium and phosphorus (Hammam et al.,2020). Domiati or Damietta cheese is the most popular soft white cheese variety in Egypt. It is consumed fresh or ripened in salted whey for 4-8 months . It differs chiefly from other pickled varities in that, the salt is added directly to the milk before renneting. It is produced from buffalo or cow milk or mixture from them (Hamad, 2015) or sheep's and goats milk or reconstituted whole or skimmed milk (Hellmuth and Brink ,2013) or ultrafiltrated whole cow and buffalo milk. The percentage of the salt differs to the season of manufacture and the ripening temperature of the cheese . In general salt is added at a level of 8-10\% in winter and $12-14 \%$ in the summer. Milk coagulated at $38^{\circ} \mathrm{C}$ and coagulation take time took about $2-3 \mathrm{~h}$. The chemical composition in these cheese is primarily influenced by the type of milk used (Robinson and Tamime ,1991 and Ayad ,2009).

As raw milk is generally utilized in this cheese manufacture, the produced cheese should not be eaten except after 60 days of storage to inactivate the pathogens but these conditions could not kill all of the pathogens (Shehata et al., 2007).

The developments in processing technology packaging sales techniques have led to a widening of choice of fresh and pickled white cheese available to the consumers. Unfortunately, there is no data reported about the chemical and microbiological of pickled white soft cheese consumed in Minia governorate, so the objective of this study was carried out to evaluate the chemical and microbiological quality of white pickled cheese consumed in some districts of Minia governorate.

\section{MATERIAL AND METHODS \\ 2.1 Materials:}

In this study 24 random samples of unpacked white pickled soft cheese samples were collected from 


\section{Scientific Journal of Agricultural Sciences 3 (2): 277-283, 2021}

different local markets in Minia Governorate, the samples were put in sterile plastic bags and transferred directly to an insulated ice box. The samples (200 gm) were divided into two parts (100 gm each). The first part was examined for chemical analysis while the second part was microbiologically examined. Samples were divided into six brands, each brand include four samples .

\subsection{Chemical analysis:-}

Moisture, fat and ash contents were determined according to A.O.A.C (2012).

Titratable acidity and $\mathrm{pH}$ was measured by the method described by (Hooi et al. 2004).

Total nitrogen (TN) and Soluble nitrogen (SN) contents were determined using kjeldahl \& semi micro kjeldahl method as described in A.O.A.C (2012), respectively.

Calcium was determined using the EDTA titration method according to Pearce (1979).

Ammonium molybdate method was used for Phosphorus determination as described by A.O.A.C (2012).

\subsection{Microbiological analysis:-}

One gram of each sample of white pickled soft cheese was serially diluted with $9 \mathrm{ml}$ of $0.1 \%$ peptone water. Appropriate dilutions were plated on MRS agar (for lactobacilli), and incubated anaerobically at $37^{\circ} \mathrm{C}$ for $72 \mathrm{hrs}$; and on M17(for lactococci ) incubated aerobically at $37^{\circ} \mathrm{C}$ for $48 \mathrm{hrs}$ The total vible counts were recorded ( Standard method for the examination of dairy products , 1978). Aerobic plate count was determined according to APHA, (1998). The number of colony forming units $(\mathrm{cfu} / \mathrm{g}$ ) was determined by surface-spread technique onto Sorbitol MacConkey agar (Oxoid) for enumeration of E. coli plates were incubated at $37^{\circ} \mathrm{C}$ for $24-48 \mathrm{hrs}$ and then counted for viable organisms (Roberts and Greenwood, 2003). Yeasts and moluds were enumerated in pour-plates of oxytetracycline potato dextrose agar (Oxoid) after incubation at $25^{\circ} \mathrm{C}$ for $3-$ 5 days. Total yeasts and moulds counts were carried out according to NMKL (1999). Enterobacteriaceae was detected according to APHA, (1998). Coliform were carried out according to APHA (1998). Salmonella spp was detected by enrichment technique according to the procedure outlined in ISO (2001).

\section{RESULTS AND DISCUSSION}

\subsection{Gross chemical composition}

Compositional analysis of white pickled soft cheese for each brand is summarized in Table (1) and Table (2). Data show variation in chemical composition between brands. $\mathrm{pH}$ ranged from 4.00 4.3 , averaged 4.2 in brand No (5) while, $\mathrm{pH}$ for band $\mathrm{No}(1)$ is similar to brand $\mathrm{No}(3)$, the average $\mathrm{PH}$ was 4.4. Also brand No (2) and brand No (6) the average of $\mathrm{pH}$ was 4.6. The titratable acidity (\%) of the brand No (5) was the lowest value compared to other brands, while brand No (6) recorded the highest value 3.3\%. These results nearly similar by Hamad (2015), who found that ripening of white cheese lead to decreasing in $\mathrm{pH}$ values from 4.3 to 3.32 after storage at 3 and 6 months, respectively.

Table 1. Gross composition analysis of white pickled soft cheese samples in Minia governorate

\begin{tabular}{clllll}
$\begin{array}{c}\text { Brand } \\
\text { No }\end{array}$ & \multicolumn{1}{c}{ pH } & \multicolumn{1}{c}{$\begin{array}{c}\text { Titratable } \\
\text { acidity } \%\end{array}$} & \multicolumn{1}{c}{ Fat \% } & \multicolumn{1}{c}{ Ash \% } & TS total solids \% \\
\hline \multirow{2}{*}{1} & $4.413 \pm 0.065$ & $2.888 \pm 0.264$ & $23.75 \pm 1.451$ & $6.961 \pm 0.2722$ & $44.50 \pm 2.164$ \\
& $(4.300-4.600)$ & $(2.200-3.350)$ & $(20.00-27.00)$ & $5.690-7.830$ & $39.15-49.73$ \\
2 & $4.645 \pm 0.175$ & $2.513 \pm 0.253$ & $18.13 \pm 1.586$ & $8.563 \pm 0.7729$ & $43.47 \pm 2.308$ \\
& $(4.350-5.100)$ & $(2.050-3.000)$ & $(15.00-22.50)$ & $4.960-10.32$ & $37.83-49.11$ \\
3 & $4.355 \pm 0.049$ & $2.863 \pm 0.226$ & $21.75 \pm 1.315$ & $8.379 \pm 0.4875$ & $42.85 \pm 1.676$ \\
& $4.280-4.490)$ & $(2.200-3.200)$ & $(18.00-24.00)$ & $6.160-10.25$ & $39.60-47.15$ \\
4 & $4.318 \pm 0.039$ & $3.225 \pm 0.286$ & $23.50 \pm 3.323$ & $7.109 \pm 0.5127$ & $43.35 \pm 4.521$ \\
& $4.230-4.420)$ & $(2.650-4.000)$ & $(14.00-29.50)$ & $4.950-8.880$ & $31.79-53.10$ \\
5 & $4.210 \pm 0.078$ & $2.350 \pm 0.509$ & $25.88 \pm 2.249$ & $7.814 \pm 0.4510$ & $48.72 \pm 2.144$ \\
& $(4.010-4.340)$ & $(1.400-3.750)$ & $(19.50-30.00)$ & $6.750-10.10$ & $44.80-54.00$ \\
6 & $4.618 \pm 0.344$ & $3.313 \pm 0.157$ & $18.88 \pm 2.105$ & $7.956 \pm 0.4916$ & $41.52 \pm 1.040$ \\
& $(4.180-5.640)$ & $(3.000-3.750)$ & $(15.50-25.00)$ & $5.750-9.110$ & $38.65-43.33$ \\
\hline
\end{tabular}

Data in parenthesis are minimum and maximum values of four samples, Results are expressed as mean value \pm standard error. 
The obtained data for fat content showed that, the lowest content was observed in brand No2 $(18.1 \%)$ and $18.9 \%$ for brand No 6, while , the highest fat content was 25.9 for brand No 5. Values for fat content were similar to the results obtained by Abdou et al (1976) who found that fat content of pickled white cheese after four months storage was about $25 \%$. Also, the same results obtained by Neamat et al, (2012). According to the data obtained by Hamouda (2020), the increase of fat content is due to the increase in total solids .

Data in Table (1) showed that there was no variation among brands in protein content . protein content ranged between 19.4-19.9\% for each brands .These results were higher than those reported by Neamat et al (2012) for Estanpoly unpacked white cheese who found that the average protein content was $5.88-10.5 \%$ for samples collected from different markets in Cairo. The present data also showed that protein content was higher than that obtained by Hamouda (2020) for white pickled cheese at 30 days storage being $15.6 \%$. The lowest value of ash content was $7 \%$ in brand No1 while the highest value was $8.6 \%$ in brand No 2 , results were higher than those obtained Hamad ( 2015 ) who reported that ash content was 4.55, 5.01 and 6.12 after 1,3 and 6 months of storge. TS total solids content were quite large being as low as 41.5 in brand No 6 high in brand No 5 $(48.74 \%)$. These results were lower than those obtained Hamad ( 2015 ) who found that TS was 53.6 after 1 month of storage in white soft pickled cheese.
According to the Egyptian Standard, (EGSQ, 2005), the moisture content of Domiati cheese must not be higher than $60 \%$ and the salt content must not be more than $9 \%$. In current study, twenty one of the tested samples were met the EGSQ, 2005 in the category of moisture while only seven samples met the EGSQ, 2005 in salt content .

Total nitrogen percentages of white pickled soft cheese are shown in Table (2). For all tested cheese the average of total nitrogen was between 2.9$3.15 \%$, total nitrogen in brand No 1 was the highest value compared to the other brands, recorded $3.15 \%$, while in brand No 6 was the lowest being $2.9 \%$. Data also showed that the soluble nitrogen content ranged between $(0.25-0.27)$ for all tested cheese .These data were lower than reported by Abdou et al,(1976), who found that the soluble nitrogen was $0.5 \%$ in 4 months old Domiati cheese made by coagulating the milk with calf rennet. The differences in soluble nitrogen in the present data compared to the others could be due to different factors such as type of milk, age of cheese , coagulant agent and percentage of salt and moisture content . Low percentage of soluble nitrogen was due to restricted proteolysis , may be due to the high concentration of salt in cheese (Table 2). The soluble proteolysis products resulted from the Domiati cheese during ripening mixed with the brine to keep the stability with their content in the cheese (Hayaloglu, 2017).

Table 2. Total nitrogen (TN), Water soluble nitrogen(WSN), salt, calcium and phosphorus content of white pickled soft cheese in Minia governorate :

\begin{tabular}{lllllll}
\hline $\begin{array}{c}\text { Brand } \\
\text { No }\end{array}$ & \multicolumn{1}{c}{ TN \% } & \multicolumn{1}{c}{ SN\% } & \multicolumn{1}{c}{ SN/TN } & \multicolumn{1}{c}{$\begin{array}{c}\text { Salt } \\
\text { NaCl\% }\end{array}$} & $\begin{array}{c}\text { Calcium } \\
\mathbf{m g} / \mathbf{1 0 0 g}\end{array}$ & $\begin{array}{c}\text { Phosphorus } \\
\mathbf{m g} / \mathbf{1 0 0 g}\end{array}$ \\
\hline \multirow{2}{*}{1} & $3.15 \pm 0.17$ & $0.26 \pm 0.028$ & $8.36 \pm 0.649$ & $9.78 \pm 4.28$ & $1651 \pm 3.86$ & $368 \pm 60.6$ \\
& $(2.94-3.36)$ & $\mathrm{N} \mathrm{ib}(0.23-0.29)$ & $6.990-10.00)$ & $(6.55-11.09)$ & $(1648-1656)$ & $(268-411)$ \\
2 & $3.05 \pm 0.21$ & $0.250 \pm 0.036$ & $8.133 \pm 0.876$ & $10.44 \pm 1.40$ & $400 \pm 86.0$ & $268 \pm 1.29$ \\
& $(2.8-3.29)$ & $(0.20-0.294)$ & $6.250-10.53)$ & $(9.23-11.66)$ & $(300-510)$ & $(267-270)$ \\
3 & $3.12 \pm 0.15$ & $0.27 \pm 0.023$ & $8.47 \pm 0.309$ & $9.11 \pm 0.61$ & $1042 \pm 1.89$ & $278 \pm 14.69$ \\
& $(2.94-3.29)$ & $(0.24-0.29)$ & $7.610-8.970)$ & $(8.26-9.72)$ & $(1041-1045)$ & $(270-300)$ \\
4 & $2.98 \pm 0.41$ & $0.27 \pm 0.022$ & $8.70 \pm 0.909$ & $7.29 \pm 2.86$ & $312 \pm 2.51$ & $263 \pm 3.82$ \\
& $(2.65-3.30)$ & $(0.23-0.28)$ & $6.120-10.53)$ & $(4.73-10.20)$ & $(310-316)$ & $(260-268)$ \\
5 & $3.08 \pm 0.12$ & $0.26 \pm 0.18$ & $8.31 \pm 0.418$ & $11.30 \pm 0.46$ & $1042 \pm 16.07$ & $279 \pm 14.8$ \\
& $(2.94-3.22)$ & $(0.23-0.28)$ & $(7.610-9.520)$ & $(10.66-11.66)$ & $(1036-1050)$ & $(270-300)$ \\
6 & $2.90 \pm 0.32$ & $0.26 \pm 0.035$ & $8.91 \pm 1.122$ & $10.08 \pm 1.14$ & $1410 \pm 4.56$ & $310 \pm 9.39$ \\
& $(2.85-3.22)$ & $(0.22-0.29)$ & $6.840-11.55)$ & $(9.23-11.66)$ & $(1008-1016)$ & $(299-322)$ \\
\hline
\end{tabular}

Data in parentheses are minimum and maximum values of four samples, Results are expressed as mean value \pm standard error 


\section{Scientific Journal of Agricultural Sciences 3 (2): 277-283, 2021}

Data in Table (2) also showed that the percentages of SN/TN for all tested brands were between $8.13-8.91 \%$

Robinson and Tamime (1991) concluded that the maturity of index of cheese is mainly due to the protein breakdown occurred by the growth and activities of microflora and or proteolysis with proteolytic enzymes .

The obtained data for calcium content shown that the highest average was observed in brand No1 $(1651 \mathrm{mg} / 100 \mathrm{~g})$ followed by $1410 \mathrm{mg} / 100 \mathrm{~g}$ in brand No5 and 1042 in brand No3, the lowest content was $312 \mathrm{mg} / 100 \mathrm{~g}$ for brand No 4 . Omar and Buchheim, (1983) found that the calcium content was 960 $\mathrm{mg} / 100 \mathrm{~g}$ for white pickled soft cheese in 2 months old made from cow's milk .

Phosphorus content of cheese showed that the lowest value was $263 \mathrm{mg} / 100 \mathrm{~g}$ in brand No 4 , despite the highest average of Phosphorus (368) was in brand
No 1. These results were lower than that recorded by Neamat et al (2012) who found that phosphorus content was from 760 to $1270 \mathrm{mg} / 100 \mathrm{~g}$ in unpacked white soft pickled cheese .

\subsection{Microbiological examination of servied cheeses:}

Cheese samples were analyzed for their microbiological quality. The quality and safety of Domiati cheese are strictly related to their microbial content. The microbial counts of cheese samples are shown in (Table 3 ). The APC ranged between $1 \times 10^{4}$ and $1.9 \times 10^{6} \mathrm{cfu} / \mathrm{g}$ (Table 3). Aly et al. (2007), Sayed et al. (2011) and El-kholy et al.,(2014) reported mean APC in Domiati cheese as $2.6 \times 10^{5}, 1.1 \times 10^{6}$ and $7.55 \times 10^{4} \mathrm{cfu} / \mathrm{g}$, respectively. In this study, the mean APC w as $4.8 \pm 1 \times 10^{5}$ which turned out to be similar to the previously mentioned studies.

Table 3. Microbiological examination of white pickled soft cheese in Minia governorate :

\begin{tabular}{llllll}
\hline Microrganisms & \multicolumn{2}{c}{ Positive samples } & Min & Max & Mean \pm SE \\
& Number & \% & & & \\
\hline Aerobic plate count ( APC ) & 24 & 100 & $1 \times 10^{4}$ & $1.9 \times 10^{6}$ & $4.8 \pm 1 \times 10^{5}$ \\
Lactococci & 24 & 100 & $1 \times 10^{2}$ & $2 \times 10^{4}$ & $5.7 \pm 1 \times 10^{3}$ \\
Lactobacilli & 24 & 100 & $1 \times 10^{4}$ & $3.5 \times 10^{5}$ & $1.6 \pm 0.2 \times 10^{5}$ \\
Molds and yeasts & 19 & 79 & $1 \times 10^{3}$ & $6 \times 10^{5}$ & $5.1 \pm 0.35 \times 10^{5}$ \\
E.coli & 7 & 29 & $1 \times 10^{1}$ & $2 \times 10^{2}$ & $3.7 \pm 0.1 \times 10^{1}$ \\
Coliform & 14 & 58.3 & ND & ND & ND \\
Enterobacteriacae & 10 & 41.5 & ND & ND & ND \\
Samonella & 2 & 9 & ND & ND & ND \\
\hline
\end{tabular}

$\mathrm{ND}=$ Not Determined , Results are expressed as mean value \pm standard error

The mean value of lactococci in cheese samples $w$ as $5.7 \pm 1 \times 10^{3}$ however, lactobacilli $w$ as found in higher level $1.6 \pm 0.2 \times 10^{5}$.

Adding $7.5 \%$ of salt to the milk resulted in the presence of lactococci as the predominant of LAB in Domiati cheese, which is recently substituted by lactobacilli .Increasing the addition of salt to $15 \%$ led to the presence of micrococci and lactobacilli as the majority of LAB. Enterococci were isolated from Domiati cheese, which exhibits high esterolytic activities (Litopoulou-Tzanetaki, 2007).

From the obtained results, it is obvious that mean value of yeast and mold counts of cheese samples was $5.1 \pm 0.35 \times 10^{5}$, which is higher than the Egyptian Standards Limits (mold content must not exceed $10 \mathrm{cfu} / \mathrm{g}$, while yeast must not exceed 400 $\mathrm{cfu} / \mathrm{g})$. The high incidence may attribute to the numerous sources of cheese contamination. It may be contaminated through milk used, washing water, environment, utensils and equipment, as well as through persons taking part in manufacturing and handling the product (Mullan, 2007). The public health importance of moluds has been emphasized as certain species can produce mycotoxins, which may induce food poisoning and neoplastic diseases including leukemia and other cancers among consumers. Also, some species of Penicillium have been associated with pulmonary and urinary tract infections in man (Brown, et al., 2007).

Coliforms were detected in $58.3 \%$ of the examined Domiati cheese samples (Table 3). These values were lower than those obtained by Meshref and Hassan (2009) who found 78\% of their samples were contaminated with coliform bacteria and higher than those reported by Amin et al. (2001), Aly et al. (2007) and Sayed et al. (2011) as they found 38, 52.5 and $20 \%$ of the samples were contaminated with coliforms, respectively. High levels of coliforms in cheese may sometimes give rise to early blowing or gassing of the product, which is characterized by large gas holes and a spongy texture of the cheese that 
generally occurs 1-2 days after it was manufactured (Bintsis , 2006).

The existence of coliforms may not necessarily indicate a direct fecal contamination of Domiati cheese, but is more likely as an indicator of poor manufacturing conditions and lack of hygiene especially during cheese marketing. The survival of coliforms in Domiati cheese is affected by the level of salt added to the cheese milk. Not less than $9.5 \% \mathrm{NaCl}$ should be added to the milk to suppress the growth of coliforms in the product, especially in cheeses made from raw milk (Abd-El Salam and Benkerroum, 2006). In this study, the salt concentration of the cheese ranged from 4.37 to $11.66 \%$ and the average value was $9.77 \%$ (Table 2). It seems that the salt content of Domiati cheese is favorable for the growth of coliforms, these results are in accordance with those obtained by El-kholy et al., (2014) .

$E$. coli and coliforms are often used as indicator microorganisms and the presence of $E$. coli implies a risk that other enteric pathogens may be present in the sample. E. coli was isolated from seven samples constituting about (29\%) of the total samples (Table 3). Moreover, the mean count of E. coli was $3.7 \pm 0.1 \times 10^{1} \mathrm{cfu} / \mathrm{g}$ (Table 3 ). The contamination rate in cheese samples was generally higher than those reported by El-Gamal and Abdel-Khalek (1997), Meshref and Hassan (2009) Sayed et al. (2011) and El-kholy et al., (2014) as they found 16, 6,4 and 26\% of their samples were contaminated by $E$. coli, respectively. On the contrary, higher incidence rates were reported by Kaldes (1997) and Amin et al. (2001) as they found 60 and $37.89 \%$ of the samples were contaminated with $E$. coli, respectively. According to the Egyptian Standards (2005), E. coli should be absent in Domiati cheese; all positive samples failed to meet the national standard. The presence of $E$. coli in Domiati cheese samples indicates an extensive deficiency of satisfactory sanitary practices during cheese manufacturing and/or post-production handling.

Salmonella was detected in 2 samples represent $9 \%$ of the tested samples. In contrast, the same microbial group was not detected in a similar survey carried out in Cairo and Giza regions studied by Aly et al.,(2007). The presence of Salmonella in some tested samples may be due to the unhygienic conditions in the production.

The present different types of microbial groups in this type of cheese was expected as it was manufactured from raw milk .
From the foregoing results, the obvious need for criteria or standard methods for white pickled soft cheese is necessary .

\section{REFERENCES}

Abd-El Salam M, Benkerroum N (2006). North African brined cheese. In Brined Cheeses (A. Tamime, ed.) pp. 139-187, Blackwell Publishing Ltd, Oxford, UK.

Abdou SM, Ghita I, El-Shibiny S (1976). Use of microbial rennets and pepsin in the manufature of Domiati cheese. Egypt. J. dairy Sci. 4, 147.

Aly SA, Morgan SD, Moawad AA, Metwally BN (2007). Effect of moisture, salt content and $\mathrm{pH}$ on the microbiological quality of traditional Egyptian Domiati cheese. Assiut Vet. Med. J. 53(115), 68-81.

Amin AA, El-Liboudy A, Nazem AM, Bakhieat AA, Kheuralla $H$ (2001). Microbial criteria of Damietta and Kariesh cheese in Bohaira governorate. The Second International Scientific Conference. Faculty of Veterinary Medicine, Mansoura University, 8-9 April, Part I, 183-199.

AOAC (2012). Association of official analytical chemists, Official methods of analysis, 19th (Ed), Vol (2), Arlington VA.USA

APHA (1998). Standard methods for the examination of water and wastewater. 20 th edn,APHA Inc, Washington DC.

Ayad EHE (2009). Starter culture development for improving safety and quality of domiati cheese. Food Microbiol. 26,533-541.

Bintsis T (2006). Quality of the brine. In Brined Cheeses (A. Tamime, ed.) pp. 264-301, Blackwell Publishing Ltd, Oxford, UK.

Brown JA, Feegeding EA, Drake M, Daubert C (2007). Microbial quality and presence of mold in soft cheese. Int. J. Food Microbiol. 115 (3) 376-380.

EGSQ (2005). Egyptian Standards For Soft CheeseDomiati Cheese (2005). Part 3 Es.1008-3/2005.

El-Gamal A, Abdel-Khalek A (1997). Quality control ofDomiati cheese in El-Dakahlia province. Alex. Vet. Sci., 13 (6)784-790.

El-Kholy AM, El-Shinawy SH, Meshref AMS, Korany AM (2014). Screening of antagonistic activity of probiotic bacteria against some foodborne pathogens. J. Appl. Environ. Microbiol. 2(2), 53-60.

Hamad MNF (2015). Comparative study between traditional Domiati cheese and recombined Feta cheese. Indian J. Dairy Sci. 68(5) 442-452.

Hammam ARA, Elfaruk MS, Ahmed ME, Sunkesula V (2020). Characteristics and Technological Aspects of the Egyptian Cheeses. Int. J.Curr.Microbiol.App.Sci .9(6): 3338-3354. 
Hamouda MEA (2020). Manufacture of probiotic low fat white soft cheese .M.sc (dairying ) Assuit university.

Hayaloglu AA (2017). Cheese Varieties Ripened Under Brine, in: Fox, P.F., McSweeney, P.L.H., Cogan, T.M., Guinee, T.P. (Eds.), Cheese: Chemistry, Physics and Microbiology: Fourth Edition. Academic Press, pp. 997-1040. https://doi.org/10.1016/B978-012-417012-4.00039-9.

Hellmuth K, Brink JM (2013). Microbial production of enzymes used in food applications, in: McNeil, B., Archer, D., Giavasis, I., Harvey Enzymes and Nutraceuticals L.B.T.-M.P. of F.I. (Eds.), Microbial Production of Food Ingredients, Enzymes and Nutraceuticals. Elsevier, pp. 262287.https://doi.org/10.1533/9780857093547.2.262.

Hooi R, Barbano DM, Bradley RL, Budde D, Bulthaus M, Chettiar M, Lynch J, Reddy R (2004). Chapter 15: Chemical and Physical Methods. Standard Methods for the Examination of Dairy Products .;480-510.

ISO (2001). Microbiology-general guidance on methods for the detection of Salmonella, 2nd ed., rev. ISO 6579. International Organization for Standardization, Geneva.

Kaldes, Y.T. (1997). Microbiological examination of soft cheeses manufactured in Minia city. Assiut Vet. Med. J. 38(75), 39-47.

Litopoulou-Tzanetaki E (2007). Soft-ripened and fresh cheeses: Feta, quark, halloumi and related varieties, in: Weimer, B.C. (Ed.), Improving the Flavour of Cheese. Elsevier, pp. 474-493. https://doi.org/10.1533/9781845693053.4.474

Meshref AMS, Hassan GM (2009). Bacteriological status of some soft cheeses sold in Beni-Suef city. Assiut Vet.Med. J. 55(122), 112-123.
Mullan WM (2007). Classification of cheese types using calcium and pH. J. Dairy Sci. and Food Technol. 28 (4) 200-209.

Neamat IB, Abdel-Salam AF, Zeinab M, AbdelGhany, Abol- Ela MF, El- Karamany AMM, Atwa MA (2012) . Chemical properties and microbiological quality for handling white cheese and effect of goat and camal milk on some pathogenic bacteria J. Food and Dairy Sci., Mansoura Univ., Vol. 3 (12): 647 667.

NMKL (Nordic Committee on Food Analysis) (1999). Quality Assurance Guidelines for Microbiological Laboratories. Report No. 98, 3rd edition.

Omar MM, Buchheim W (1983). Composition and Microstructure of Soft Brine Cheese Made From Instant Whole Milk Powder. J. Food Struct. 2, 43-50. Pearce KN (1979). The complexometric determination of calcium in dairy produts. NewZeland . J.Dairy Sci., Tech. 12,13

Roberts D, Greenwood M (2003). Practical Food Microbiology, 3rd Ed., Blackwell Publishing Ltd, Oxford, UK.

Robinson RK, Tamime AY (1991). Feta and related cheeses first published by Ellis Horwood limited, market cross house, cooper street ,chichesler, England Sayed M, Ahmed AAH, Shaban W (2011). Microbiological evaluation of some Egyptian white soft cheeses. Benha Vet. Med. J. 1, 1-6.

Shehata A, Magdoub M, Fayed E, Hofi A (2007). Effect of salt on the properties of pickled Domiati cheese. Egyptian Journal Dairy Science 45 (1) 47-54. Standard Methods for the Examination of Dairy products. (1978). A publication of American public Health Assoc .Broadway, New York , NY.U.S.A. 


\title{
الملخص العربي
}

\section{تقييم الجوده الكيمياويه والميكروبيولوجيه للجبن الابيض الطري المخزن والمستهلك في محافظه المنيا}

\author{
رغده مختارسيد معوض' و اسامه صفوت فوزي خليل'

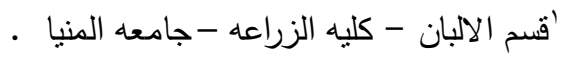

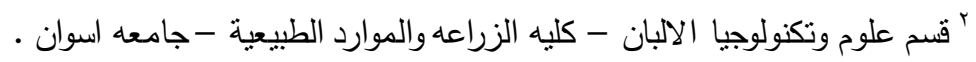

تهدف هذه الدراسه الي تقييم الصفات الكيميائيه والجوده الميكروبيولوجية لعينات من مناطق مختلفه بمحاغظه المنيا ،اجريت الدراسه علي ع ب عينه

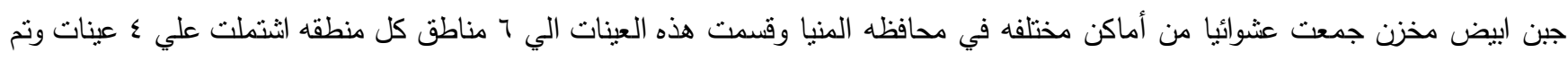
تحليل هذه العينات كيماويا وميكروبيولوجيا.

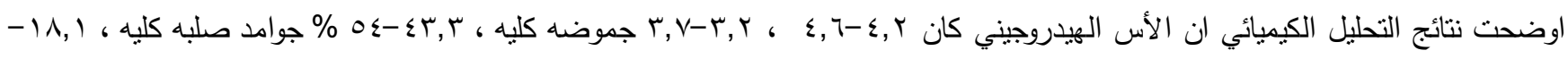

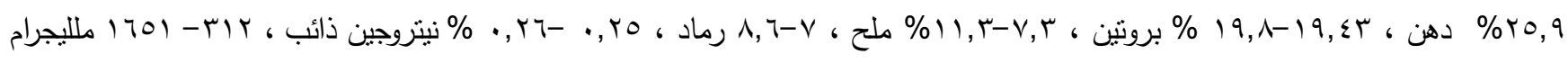

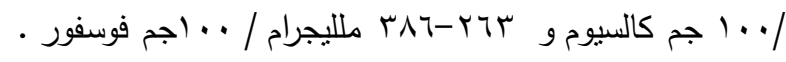

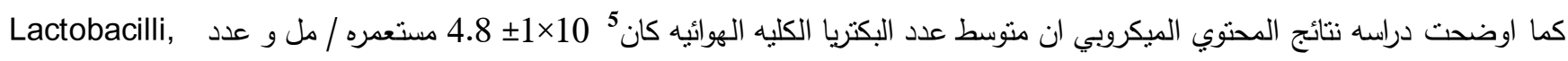
كانوا $\quad$ Lactococci

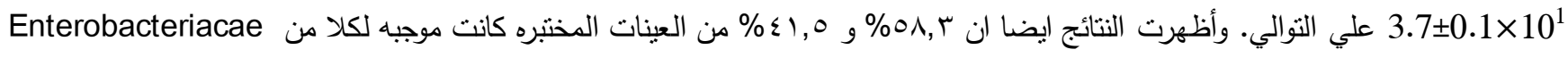

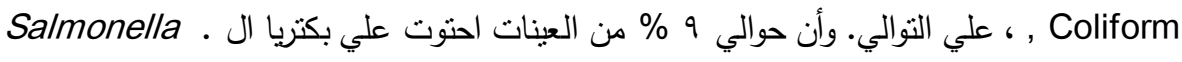
واستخلصت الدراسه الحاجه الماسه لتصنيع الجبن الإيض الطري المخزن الجبن بطرق متمشيه مع المعايير و المواصفات القياسيه. 